\title{
The Impact of Selected Essential Oils Applied to Non-Woven Viscose on Bacteria That Cause Lower Urinary Tract Infections-Preliminary Studies
}

\author{
Emilia Frydrysiak $^{1, *}$, Alina Kunicka-Styczyńska ${ }^{2}$, Krzysztof Śmigielski $^{3, *}$ and Michał Frydrysiak ${ }^{4}$ \\ 1 Faculty of Biotechnology and Food Sciences, Institute of Natural Products and Cosmetics, \\ Lodz University of Technology, Stefanowskiego 4/10, 90-924 Lodz, Poland \\ 2 Faculty of Biotechnology and Food Sciences, Institute of Fermentation Technology and Microbiology, \\ Lodz University of Technology, Wólczańska 171/173, 90-924 Lodz, Poland; alina.kunicka@p.lodz.pl \\ 3 Department of Environmental Biotechnology, Faculty of Biotechnology and Food Sciences, \\ Lodz University of Technology, Wólczańska 171/173, 90-924 Lodz, Poland \\ 4 Department of Knitting Technology and Textile Machines, Institute of Fermentation Technology and \\ Microbiology, Lodz University of Technology, Żeromskiego 116, 90-924 Lodz, Poland; \\ michal.frydrysiak@p.lodz.pl \\ * Correspondence: em.frydrysiak@gmail.com (E.F.); krzysztof.smigielski@p.lodz.pl (K.Ś.)
}

Citation: Frydrysiak, E.; Kunicka-Styczyńska, A.; Śmigielski, K.; Frydrysiak, M. The Impact of Selected Essential Oils Applied to Non-Woven Viscose on Bacteria That Cause Lower Urinary Tract Infections-Preliminary Studies. Molecules 2021, 26, 6854. https:// doi.org/10.3390/molecules26226854

Academic Editors: Sotiris Hadjikakou, Christina N. Banti and Andreas K. Rossos

Received: 19 September 2021 Accepted: 11 November 2021 Published: 13 November 2021

Publisher's Note: MDPI stays neutral with regard to jurisdictional claims in published maps and institutional affiliations.

Copyright: (c) 2021 by the authors. Licensee MDPI, Basel, Switzerland. This article is an open access article distributed under the terms and conditions of the Creative Commons Attribution (CC BY) license (https:// creativecommons.org/licenses/by/ $4.0 /)$.

\begin{abstract}
Inflammation of the lower urinary tract is a very common problem, which occurs particularly in women. A concept of a biotextronics system for preventive and support treatment of lower urinary tract inflammations was presented. The system includes a non-woven viscose insert for essential oils application. The oils were deposited on the non-woven viscose and incubated in the temperature of $37^{\circ} \mathrm{C}$ and served a model for their action in the vapor phase as the element of the biotextronics system. The essential oils used in the research were the following: chamomile (Matricaria chamomilla L.), sage (Salvia officinalis L. and Salvia lavandulaefolia), juniper (Juniperus communis L.), thyme (Thymus vulgaris L.), and mixtures of chamomile oil with oils of each sage species in a 1:1 ratio. The oils were tested against Escherichia coli, Pseudomonas aeruginosa, Staphylococcus epidermidis, Staphylococcus saprophyticus, and Enterococcus faecalis. The best inhibitory effect in vapor phase was noted for chamomile essential oil at the lowest concentration $\left(0.054 \mu \mathrm{L} / \mathrm{cm}^{3}\right)$. Both mixtures of chamomile and sage acted antagonistically, lowering the antibacterial activity of the individual oils applied solely. Juniper and Salvia officinalis essential oils at the concentrations tested increased the growth of at least one of the bacteria tested. Salvia lavandulaefolia Vahl. essential oil inhibited all bacteria, only at the concentration $0.214 \mu \mathrm{L} / \mathrm{cm}^{3}$. The thyme oil, at the concentration $0.054 \mu \mathrm{L} / \mathrm{cm}^{3}$, reduced the growth of all bacterial species tested. Chamomile and thyme essential oils were chosen for further research in the biotextronics pantiliner system.
\end{abstract}

Keywords: essential oils; biotextronics system; pantiliner; lower urinary tract inflammations

\section{Introduction}

Inflammation of the lower urinary tract is a very common problem which occurs 50 times more often in women than in men, and, according to statistics, afflicts a half of women, at least once in their lives [1-4]. The main cause of lower urinary tract inflammations, including nosocomial infections, is infections is Escherichia coli [5].

E. coli, the bacteria residing in a colon, is the cause of approximately $73-95 \%$ of infections, including $53-72 \%$ of outside-the-hospital and approximately $50 \%$ of insidethe-hospital infections [5]. Other species of microorganisms causing lower urinary tract infections and their occurrences are listed in Table 1. 
Table 1. Microorganisms associated with inflammations of the lower urinary tract [3,6-8].

\begin{tabular}{cc}
\hline Microorganisms & Occurrence of Infections \\
\hline Escherichia coli & T3-95\% of infections, 53-72\% of ambulatory infections and 18-57\% of in-hospital infections \\
Staphylococcus epidermidis & $5-10 \%$ of all infections \\
Staphylococcus saprophyticus & Up to 2\% of ambulatory infections and up to $4 \%$ of in-hospital infections \\
Pseudomonas spp. & Up to $4 \%$ of ambulatory infections and 1-11\% of in-hospital infections \\
Staphylococcus spp. & $2-12 \%$ of ambulatory infections and $7-16 \%$ of in-hospital infections \\
Mainly in-hospital infections & $3 \%$ of all infections, mostly in-hospital \\
Enterobacter spp. & $3 \%$ of all infections, mostly in-hospital, often returns \\
Klebsiella spp. & $3 \%$ of all infections, mostly in-hospital \\
Proteus spp. & Mainly in-hospital infections \\
Serratia spp. & Mainly in-hospital infections; may be spread by blood \\
Mycobacterium spp. & Spread by unprotected sex \\
Neisseria gonorrhoeae & Spread by unprotected sex \\
Chalmydia trachomatis & May be spread by blood \\
\hline Candida albicans, Cryptococcus neoformans, Aspergillus spp. &
\end{tabular}

The treatment of lower urinary tract inflammations includes not only antibiotics or nitrofurantoin-based medicines, but also hip baths or steam baths with essentials oils, which are recommended by doctors to be taken from several times a week, to 2-3 times a day in the initial phase of the treatment. Hot water or steam increases blood flow, which helps the treatment, and essential oils added to the hot water support healing and relieve discomfort [2,9-12]. The treatment should be conducted for 15-20 min, which is uncomfortable and difficult to realize day-to-day. That is why the idea of a biotextronics system for protection and support of the lower urinary tract inflammation treatment, facilitating mobility, came to be. The biotextronics system combines essential oils with antibacterial activity, serving as bioactive elements of natural origin and electroconductive printing layers, enabling heating of the pantiliner. Essential oils, with antimicrobial and anti-inflammatory action, in combination with thermal action, alleviate the symptoms of the disease and reduce the multiplication of bacteria (Figure 1).

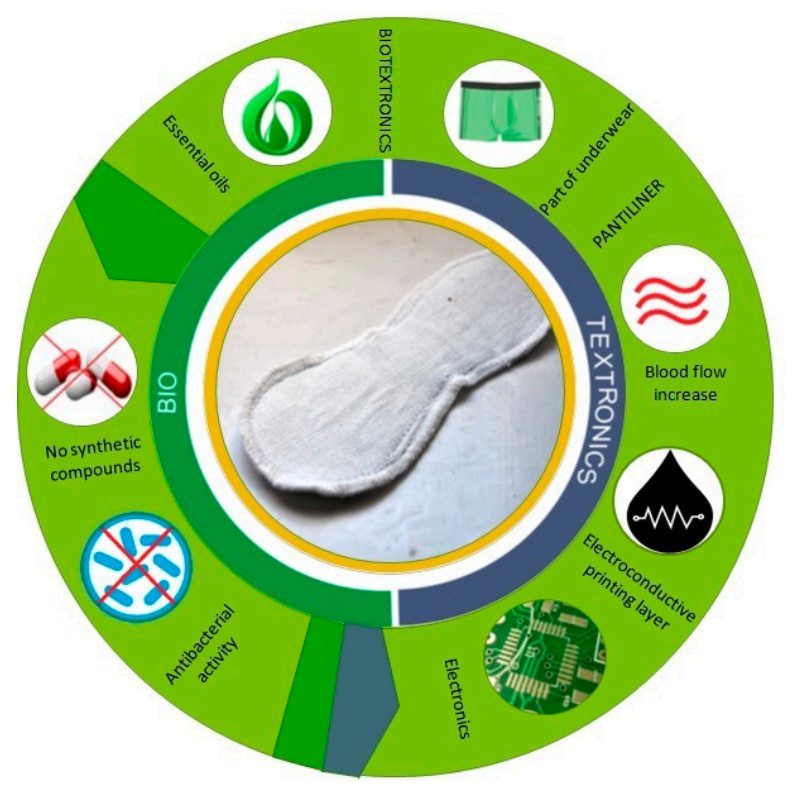

Figure 1. Functionality of the biotextronics system.

The system consists of a pro-medical underwear equipped with a regulation unit linked to a textronics heating insert and integrated with a biotextronics pantiliner with essential oils by a textile signal line. The biotextronics pantiliner consists of four main parts as follows: two insulating layers and the system heating element placed between them (Figure 2). The pantiliner maintains a constant temperature, thanks to the textronics heating insert. The pantiliner itself is a replaceable element, fixed to this personal pro-medical underwear. The higher temperature makes the essential oil release from the outer part of the biotextronics pantiliner and increases blood flow, which helps the treatment. 


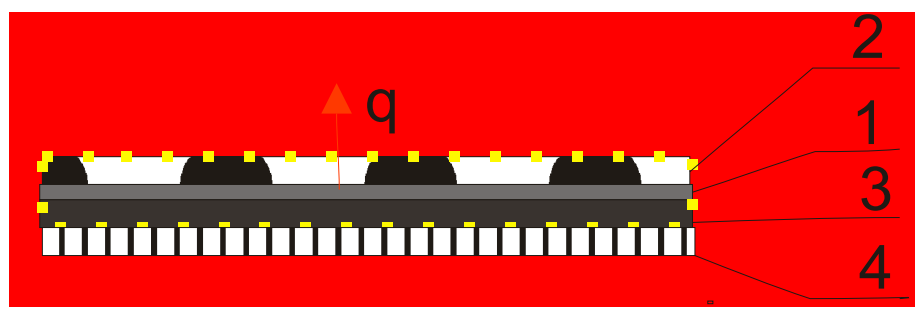

Figure 2. Diagram of the clothing package of the textronics system: 1-textronics heating insert; 2-outer insulating layer, made of non-woven viscose; 3-inner insulating layer made of woolen fabric; 4-a layer of a personal underwear; q-heat flux.

The essential oils chosen for the research express antimicrobial activity against a variety of microorganisms including pathogens.

Salvia officinalis L. essential oil was proven to have antibacterial and bacteriostatic effects against $E$. coli species concentrations of 1:100 and 1:1000. In the conducted tests, the oil was also active against microorganisms of the following genus: Aeromonas, Bacillus, Enterococcus, Klebsiella, Listeria, Micrococcus, Proteus, Pseudomonas, Salmonella, and Staphylococcus. Research showed that this essential oil is more active against gram-positive than gramnegative bacteria and its antimicrobial effect is related to the presence of camphor, $\alpha$ - and $\beta$-thujones and 1,8-cineole. The other compounds, $\alpha$ - and $\beta$-pinene, are also characterized by antimicrobial activity [13-16].

Salvia lavandulaefolia Vahl. essential oil is active against the following gram-negative bacteria: E. coli (MIC $3.4 \mathrm{mg} / \mathrm{mL}$ ), Klebsiella pneumoniae (MIC $6.9 \mathrm{mg} / \mathrm{mL}$ ), Serratia marcescens (MIC $6.9 \mathrm{mg} / \mathrm{mL}$ ), Salmonella cholearesuis (MIC $4.6 \mathrm{mg} / \mathrm{mL}$ ), and Shigella flexneri (MIC $9.2 \mathrm{mg} / \mathrm{mL}$ ); and the gram-positive bacteria: Bacillus subtilis (MIC $3.4 \mathrm{mg} / \mathrm{mL}$ ), Enterococcus faecalis (MIC $4.6 \mathrm{mg} / \mathrm{mL}$ ), Micrococcus luteus (MIC $2.8 \mathrm{mg} / \mathrm{mL}$ ), Staphylococcus aureus (MIC $2.3 \mathrm{mg} / \mathrm{mL}$ ), S. epidermidis (MIC $2.0 \mathrm{mg} / \mathrm{mL}$ ), and Streptococcus mutans (MIC $2.9 \mathrm{mg} / \mathrm{mL}$ ) [17]. The antibacterial activity of the oil is mainly attributed to the presence of 1,8-cineole, $\beta$-thujone, camphor, borneol, and $p$-cymene [18].

Matricaria chamomilla L. essential oil is recognized from its strong activity against the following gram-positive bacteria: S. aureus (MIC $0.021 \mu \mathrm{L} / \mathrm{mg}$ ), Bacillus cereus (MIC $0.032 \mu \mathrm{L} / \mathrm{mg}$ ), and B. subtilis (MIC $0.041 \mu \mathrm{L} / \mathrm{mg}$ ). A strong antibacterial effect of the chamomile essential oil was also found against the following gram-negative bacteria: Shigella shiga (MIC $0.178 \mu \mathrm{L} / \mathrm{mg}$ ), S. sonnei (MIC $0.195 \mu \mathrm{L} / \mathrm{mg}$ ), and bacteria of the genus Proteus (MIC $0.161 \mu \mathrm{L} / \mathrm{mg}$ ). The highest value of the minimum oil concentration at which bacterial growth inhibition was found was recorded for Pseudomonas aeruginosa $(6 \mu \mathrm{L} / \mathrm{mg})$ [19]. The antibacterial properties are mainly due to $\alpha$-bisabolol; however, chamazulene also has antimicrobial activity against gram-positive bacteria [20]. $\alpha$-bisabolol in the oil also has strong antifungal properties against Candida albicans, Trichophyton mentagrophytes, T. rubrum, and Staphylococcus [20,21].

Thymus vulgaris L. essential oil, due to its antibacterial properties, is extensively used since ancient times. The strongest inhibitory effect was found against Corynebacterium xerosis (MIC equal or lower than $0.12 \mathrm{mg} / \mathrm{mL}$ ). S. aureus, S. epidermidis, E. faecalis, Acinetobacter baumannii, Klebsiella pneumoniae, and Pseudomonas stutzeri (MIC $0.5 \mathrm{mg} / \mathrm{mL}$ ) also proved to be sensitive to the thyme essential oil. In relation to E. coli and Serratia marcescens, the effect of the oil was slightly weaker (MIC equal to 1.0 and $2.0 \mathrm{mg} / \mathrm{mL}$, respectively), while the weakest (MIC equal to or above $4.0 \mathrm{mg} / \mathrm{mL}$ ) was found against P. aeruginosa [22]. The thyme essential oil also shows antibacterial activity, against the following bacteria, among others: Haemophilus influenzae, Streptococcus pyogenes, Streptococcus agalactiae, and Mycobacterium smegmatis. High sensitivity to this oil was also noted for antibiotic-resistant strains of A. baumannii [23]. It also has an inhibitory effect on bacteria of the genus Salmonella [24]. Thyme oil also exhibits antiviral activity against the herpes simplex virus types 1 and 2, as well as antifungal activity against Aspergillus niger, C. albicans, and C. tropicalis [25]. 
Studies with Juniperus communis $\mathrm{L}$. essential oil have shown that it inhibits the growth of gram-positive bacteria, including the following: B. cereus, B. subtilis, E. faecalis, Listeria monocytogenes, S. aureus, and S. epidermidis; and the following gram-negative bacteria: E. coli, Klebsiella oxytoca, K. pneumoniae, Proteus mirabilis, Salmonella enteritidis, Shigella sonnei, S. marcescens, and Yersenia enterocolitica. The juniper essential oil also shows activity against fungi of the genus Candida [26,27].

The aim of the study was to determine the antibacterial activity of five selected commercial essential oils and two their mixtures against the chosen bacteria, associated with urinary tract infections and inflammations. The selection of those essential oils efficient against chosen bacteria associated with urinary tract infections is crucial for the biotextronics pantiliner's effectiveness. These preliminary studies are focusing on the oil action in the vapor phase. The oils deposited on the non-woven viscose and incubated at the temperature of $37^{\circ} \mathrm{C}$ served the model for their action as the element of the biotextronics system. The system has been patented in Poland (PAT.236378-Textronic system for prophylaxis supporting the treatment and inflammation of the lower urinary tract, https:/ / ewyszukiwarka.pue.uprp.gov.pl/search/pwp-details/P.408106 (accessed on 5 May 2014)), it was awarded with the first prize in "Innovation is a woman" competition in Poland and won three gold medals at the international exhibitions of inventions.

\section{Results and Discussion}

Antibacterial Activity of Essential Oils Applied on Non-Woven Viscose

The antibacterial volatile activity of five essential oils—chamomile Matricaria chamomilla L., sage Salvia officinalis L., Salvia lavandulaefolia Vahl., juniper Juniperus communis L., and thyme Thymus vulgaris L.- against five bacteria associated with urinary tract infections were estimated by the microatmosphere method, with three different oil concentrations in the air $\left(0.054 ; 0.106\right.$ and $\left.0.214 \mu \mathrm{L} / \mathrm{cm}^{3}\right)$. The results are presented in Figures 3-5. The results were various for each bacterium, relative to the same essential oil. Salvia officinalis L. essential oil inhibited $E$. faecalis better than other bacteria tested; however, it also stimulated the growth of E. coli. We also noticed that the higher concentration of essential oils in the atmosphere did not mean the higher bacteria biomass decrease.

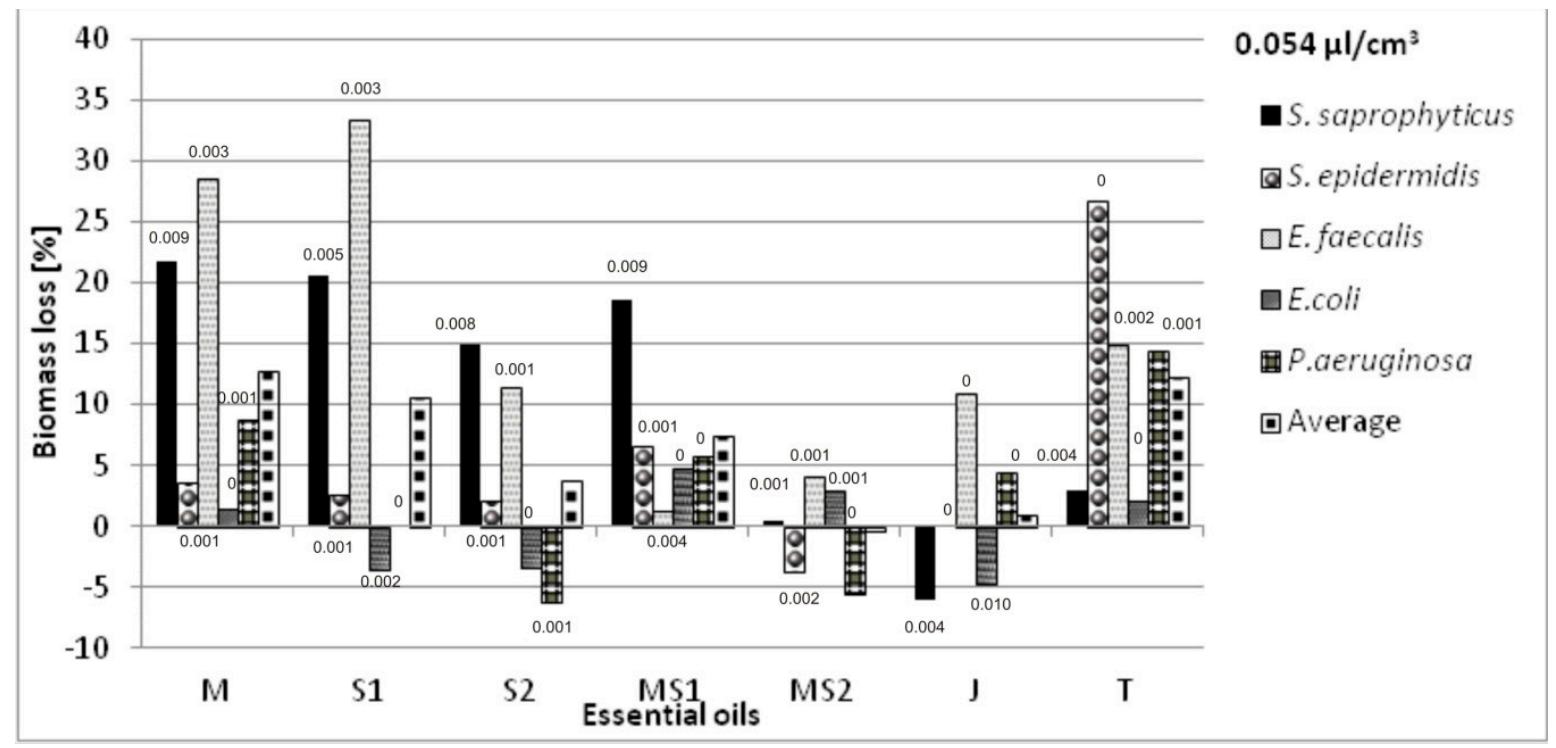

Figure 3. Antimicrobial activity of essential oils in a vapor phase at the oil concentration of $0.054 \mu \mathrm{L} / \mathrm{cm}^{3}$ in the atmosphere, where: M-Matricaria chamomilla L.; S1-Salvia officinalis L.; S2—Salvia lavandulaefolia Vahl.; MS1-Matricaria chamomilla L. with Salvia officinalis L.; MS2-Matricaria chamomilla L. with Salvia lavandulaefolia Vahl.; J-Juniperus communis L.; T-Thymus vulgaris L. Results are presented as an average value of three repetitions with $\pm \mathrm{SD}<0.01$ (values of SD placed above the bars); all the results were statistically different $(p<0.05)$. 


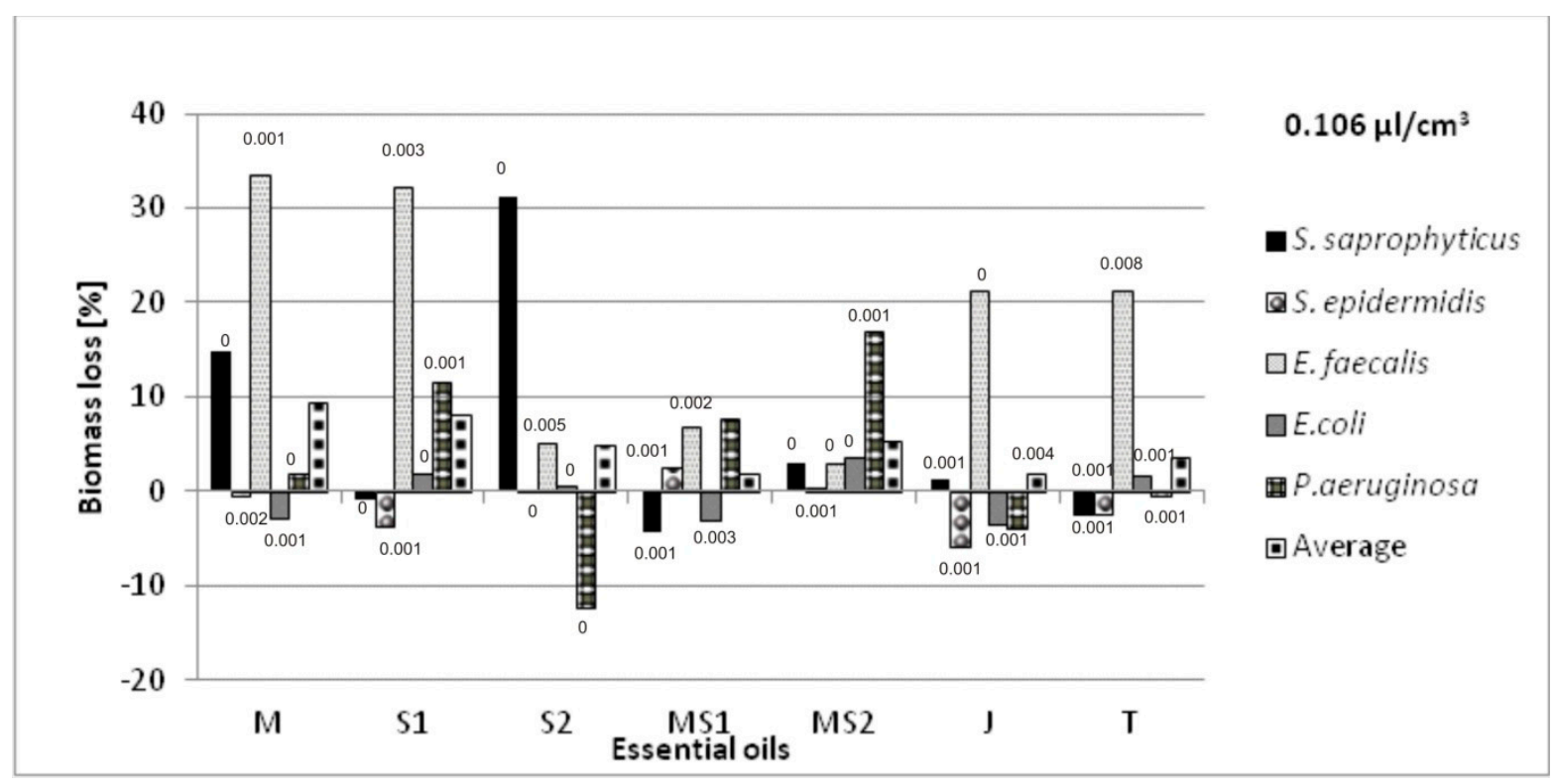

Figure 4. Antimicrobial activity of essential oils in a vapor phase at the oil concentration of $0.106 \mu \mathrm{L} / \mathrm{cm}^{3}$ in the atmosphere, where: M-Matricaria chamomilla L.; S1—Salvia officinalis L.; S2—Salvia lavandulaefolia Vahl.; MS1—Matricaria chamomilla L. with Salvia officinalis L.; MS2-Matricaria chamomilla L. with Salvia lavandulaefolia Vahl.; J—Juniperus communis L.; T—Thymus vulgaris L. Results are presented as an average value of three repetitions and with $\pm \mathrm{SD}<0.01$ (values of SD placed above the bars); all the results were statistically different $(p<0.05)$.

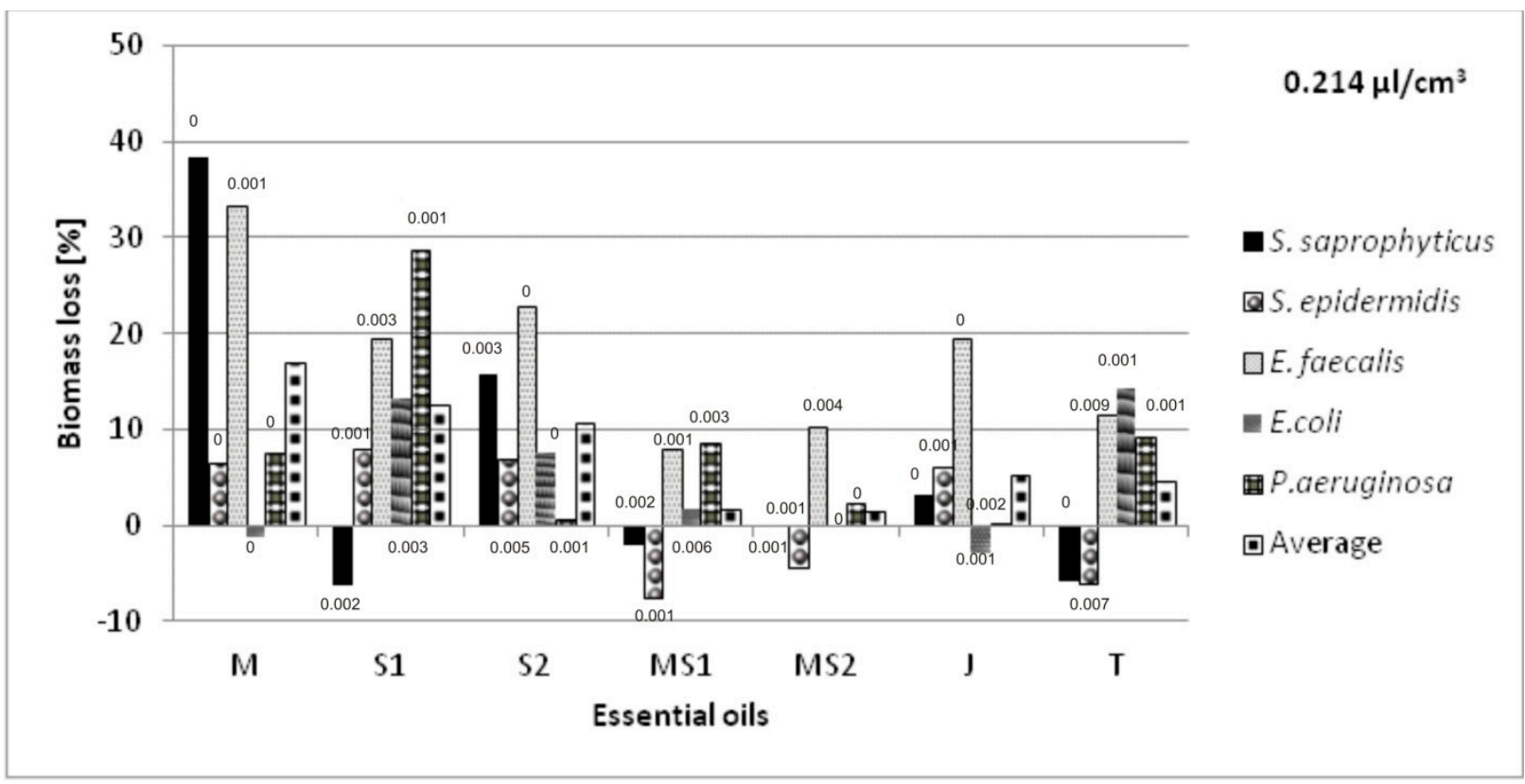

Figure 5. Antimicrobial activity of essential oils in a vapor phase at the oil concentration of $0.214 \mu \mathrm{L} / \mathrm{cm}^{3}$ in the atmosphere, where: M-Matricaria chamomilla L., S1—Salvia officinalis L., S2-Salvia lavandulaefolia Vahl., MS1—Matricaria chamomilla L. with Salvia officinalis L., MS2-Matricaria chamomilla L. with Salvia lavandulaefolia Vahl., J—Juniperus communis L., T—Thymus vulgaris L. Results are presented as an average value of three repetitions with $\pm \mathrm{SD}<0.01$ (values of SD placed above the bars); all the results were statistically different $(p<0.05)$.

We aimed to select the essential oil applied on non-woven viscose causing the greatest inhibition of bacterial growth, measured as the biomass lost compared with their growth in the cultures without the oils' vapors. The average loss of biomass for selected oils was also calculated taking into account all the bacteria species. The highest total biomass loss 
was a criterion for the selection of the essential oils intended for further research in the biotextronics system. The sets of oils' combinations, with the increase in biomass of at least one strain, were not considered as useful.

The selected essential oils applied on the material have various impacts on individual species. The greatest biomass loss was observed for Matricaria chamomilla L. essential oil against S. saprophyticus (38\%) and E. faecalis (33\%) in the highest oil concentration. However, in that concentration, it caused a slight increase in biomass of E. coli (1\%). There was also a significant increase in biomass in the microatmosphere of 0.054 and $0.106 \mu \mathrm{L} / \mathrm{cm}^{3}$ of Salvia officinalis L. against E. faecalis (33 and 32\%, respectively) and Salvia lavandulaefolia Vahl. against $S$. saprophyticus (31\%) in the microatmosphere of $0.106 \mu \mathrm{L} / \mathrm{cm}^{3}$ (Figures 3 and 4 ).

Combining chamomile essential oils with two types of sage did not bring satisfactory results. Although this oil combination increases the anti-inflammatory effect [18], the average loss of bacterial biomass was low (from -0.3 to $7 \%$ ), and at the selected concentrations, it caused an increase in biomass for some bacteria (Figures 3-5).

No increase in biomass for any of the tested bacterial strains was recorded at the following atmospheres: Matricaria chamomilla L. essential oil, its mixture with Salvia officinalis L. essential oil and Thymus vulgaris L. essential oil in the concentration of $0.054 \mu \mathrm{L} / \mathrm{cm}^{3}$; Matricaria chamomilla L. essential oil mixed with Salvia lavandulaefolia Vahl. essential oil in the concentration of $0.106 \mu \mathrm{L} / \mathrm{cm}^{3}$; Salvia lavandulaefolia Vahl. essential oil at the concentration of $0.214 \mu \mathrm{L} / \mathrm{cm}^{3}$. The highest average biomass loss with the simultaneous absence of biomass growth was observed for Matricaria chamomilla L. and Thymus vulgaris L. essential oils at 13 and $12 \%$, respectively.

According to the literature, chamomile essential oil in a vapor phase was effective against E. coli, P. aeruginosa, and S. aureus, with MIC values $2.19 \mu \mathrm{g} / \mathrm{cm}^{3}, 1.02 \mu \mathrm{g} / \mathrm{cm}^{3}$, and $1.06 \mu \mathrm{g} / \mathrm{cm}^{3}$, respectively [28]. In our research, vapors of Matricaria chamomilla L. essential oil substantially inhibited the growth of all bacteria investigated at the concentration of $0.054 \mu \mathrm{L} / \mathrm{cm}^{3}$.

The activity of Salvia officinalis L. essential oil against E. coli, S. saprophyticus, and S. epidermidis was confirmed in another study [29]. In the presented research, the oil, even at the concentration of $0.054 \mu \mathrm{L} / \mathrm{cm}^{3}$, retarded the growth of both Staphylococcus species by 20.1 and $2.6 \%$, respectively, as well as E. coli by $1.9 \%$ at the concentration of $0.106 \mu \mathrm{L} / \mathrm{cm}^{3}$. Its antibacterial activity is caused by the presence of camphor, thujone, and 1,8-cineole. Camphor was also detected in a vapor phase [29,30].

In the disc diffusion method, MICs for S. lavandulaefolia Vahl. essential oils were $3.42 \mathrm{mg} / \mathrm{mL}$ against E. coli, $4.62 \mathrm{mg} / \mathrm{mL}$ against $E$. faecalis, and $2.31 \mathrm{mg} / \mathrm{mL}$ against S. aureus [31]. We noted for both Staphylococcus species and the E. faecalis investigated that this essential oil was inhibitory in vapor phase at $0.054 \mu \mathrm{L} / \mathrm{cm}^{3}$ and for E. coli at $0.214 \mu \mathrm{L} / \mathrm{cm}^{3}$; however, the bacterial growth was reduced from 2.1 (S. epidermidis) to $14.9 \%$ (S. saprophyticus). Although these two methods cannot be compared directly, the result showed the oil action even in much smaller concentrations.

Due to the lack of literature data on the antimicrobial activity of juniper essential oil in vapors we noted its activity, measured by the disc diffusion method, where Juniperus communis L. essential oil inhibited the growth of S. epidermidis and E. faecalis, with no effect on $E$. coli [27]. In the investigation presented, in the vapor phase at $0.054 \mu \mathrm{L} / \mathrm{cm}^{3}$, the juniper oil reduced the growth of E. faecalis by $10.8 \%$, and at $0.214 \mu \mathrm{L} / \mathrm{cm}^{3}$, minimized E. faecalis development by $19.6 \%$, but did not inhibit the growth of E. coli in any of the investigated concentrations.

The volatile compounds, such as linalol, bornyl acetate, limonene, and $\gamma$-terpinolene of thyme essential oil are attributed to its biological activity. According to the literature, the MIC of thyme oil in vapor phase against $S$. aureus was $0.26 \mu \mathrm{L} / \mathrm{cm}^{3}$ [28], while in the presented research, the thyme oil at its lowest concentration $0.054 \mu \mathrm{L} / \mathrm{cm}^{3}$ reduced the growth of two species of Staphylococcus-S. saprophyticus and S. epidermidis by 2.9 and $26.7 \%$, respectively. Thymus vulgaris L. essential oil in vapor phase did not bring the expected 
ceasing of bacterial growth; however, one of its compounds, thymol, is proven to be a highly antiseptic phenol derivative [28].

Essential oils are characterized by a wide spectrum of antimicrobial action. Apart from the tested microbial strains, sage (Salvia officinalis) oil is reported to be active against other bacteria associated with lower urinary tract infections, Enterococcus sp. and Klebsiella sp. [32,33], and expresses antifungal activity against both Candida albicans [34] and Candida non-albicans pathogenic strains [35]. Thyme oil, known as a strong antibacterial and antifungal agent, is also effective against Klebsiella pneumoniae [36] and C. albicans [37]. Owing to their antimicrobial activity, the sage and thyme essential oil vapors may be helpful in cases of mixed bacterial-fungal infection of the urinary tract.

Essential oils applied topically may cause skin inflammations and allergic reactions. The research on oils toxicity towards normal human cells are scarce and researchers are rather focusing on their toxicity against cancer cells; however, essential oils may also be considered as skin penetration enhancers for transdermal delivery of drugs [38]. Safe application of oils and their vapors on human tissues relies upon the proper balance between their concentration and the exposition time. Essential oils constituents are proved to penetrate into the bloodstream but are subjected to fast metabolism or excreted with urine and feces without accumulation [38-40]. Chamomile essential oil is historically proved as a safe agent in a variety of applications, including topical ones. Aqueous and methanolic extracts of chamomile, tested against human normal cells, did not present adverse effects in contrast to their action against various human cancer cells [41]. Applied against human cancer cell lines, chamomile essential oil was characterized as a weak cytotoxic agent [42] and sage and thyme oils expressed dose-dependent cytotoxicity [43]. Among the oils tested in the present study, thyme essential oil may raise concerns, but it also has long been used in the treatment of respiratory tract infections and in the relief of pruritus associated with dermatitis and bruises. High concentrations of thyme oil may be a cause of skin irritation; however, no toxicity has been reported after its administration in lower doses [44].

\section{Materials and Methods}

\subsection{Material for Essentials Oils Application}

The part of the biotextronics pantiliner used in the research was a non-woven viscose material. Its characteristics are presented in Table 2. It originated from Lentex S.A. (Lubliniec, Poland).

Table 2. Characteristic of the non-woven viscose insert.

\begin{tabular}{cccc}
\hline Material & Function & Surface Mass $\left[\mathrm{g} / \mathrm{m}^{2}\right]$ & Thickness $[\mathrm{mm}]$ \\
\hline Non-woven viscose & External, removable insert & 30 & 0.2 \\
\hline
\end{tabular}

\subsection{Essential Oils}

In the study, the five following commercial essential oils were used: Matricaria chamomilla L., Salvia officinalis L., Salvia lavandulaefolia Vahl., Juniperus communis L., and Thymus vulgaris L.; in addition, mixtures of Matricaria chamomilla L. with each sage species in a 1:1 ratio $(v / v)$ were also used. Essential oils were purchased from Avicenna-Oil ${ }^{\circledR}$ (Wrocław, Poland) and fulfilled the requirements of good manufacturing practices. Characteristics of the essential oils are shown in Table 3. 
Table 3. Characteristics of essential oils.

\section{Matricaria chamomilla L. Essential Oil}

Organoleptic Description

Analytical Data

Chromatographic Profile clear, viscous liquid, dark blue, with a characteristic odor density (at $20^{\circ} \mathrm{C}$ ): 0.946 to $0.969 \mathrm{~g} / \mathrm{cm}^{3}$ refractive index (at $20^{\circ} \mathrm{C}$ ): $1.496-1.516$

(-)- $\alpha$-bisabolol: $10-65 \%$

chamazulene: $>1.0 \%$

bisabolol oxide and (-)- $\alpha$-bisabolol: $\geq 20 \%$

\section{Salvia officinalis L. Essential Oil}

Organoleptic Description

Analytical Data

Chromatographic Profile clear liquid, slightly yellow or slightly green, with a characteristic odor

density (at $20^{\circ} \mathrm{C}$ ): 0.905 to $0.925 \mathrm{~g} / \mathrm{cm}^{3}$

refractive index (at $20^{\circ} \mathrm{C}$ ): 1.457 to 1.473

optical rotation $\left(\right.$ at $\left.20^{\circ} \mathrm{C}\right):-3.0^{\circ}$ to $+15.0^{\circ}$

1,8-cineole: $6.0-16.0 \%$

$\alpha$ - and $\beta$-thujone: $20-40 \%$

camphor: $14.0-37.0 \%$

bornyl acetate: $\max .5 .0 \%$

borneol: $\max 5.0 \%$

\section{Salvia lavandulaefolia Vahl. Essential Oil}

Organoleptic Description

Analytical Data

Chromatographic Profile clear liquid, light yellow, with a characteristic odor

density (at $20^{\circ} \mathrm{C}$ ): 0.907 to $0.927 \mathrm{~g} / \mathrm{cm}^{3}$

refractive index (at $20^{\circ} \mathrm{C}$ ): 1.458 to 1.478

optical rotation $\left(\right.$ at $\left.20^{\circ} \mathrm{C}\right):+9^{\circ}$ to $+19^{\circ}$

flash point: $54^{\circ} \mathrm{C}$

$\alpha$-thujone: $30.3 \%$

camphor: $20.3 \%$

1,8-cineole: $12.5 \%$

$\alpha$ - and $\beta$-pinene: $0.6-5.9 \%$

borneol: $2.7 \%$

$\alpha$ - and $\beta$-caryophyllene: $1.6-2.7 \%$ bornyl acetate $1.9 \%$ $\alpha$-terpineol: $1.2 \%$

\section{Juniperus communis L. Essential Oil}

Organoleptic description

Analytical Data

Chromatographic Profile
Clear liquid, colorless or slightly yellow, with a characteristic odor density (at $20^{\circ} \mathrm{C}$ ): 0.857 to $0.876 \mathrm{~g} / \mathrm{cm}^{3}$

refractive index (at $20^{\circ} \mathrm{C}$ ): $1.471-1.483$

optical rotation $\left(\right.$ at $\left.20^{\circ} \mathrm{C}\right):-15^{\circ}$ to $-0.5^{\circ}$ $\alpha$-pinene: $20.0-50.0 \%$ sabinen: $\leq 20.0 \%$ $\beta$-pinene: $1.0-12.0 \%$ $\beta$-myrcene: $1.0-35.0 \%$ $\alpha$ - phellandrene: $\leq 1.0 \%$ limonene: $2.0-12.0 \%$ terpinen-4-ol: $0.5-10.0 \%$ bornyl acetate: $\leq 2.0 \%$ $\beta$-caryophyllene: $\leq 7.0 \%$

\section{Thymus vulgaris L. Essential Oil}

Organoleptic Description

Analytical Data

Chromatographic Profile clear, yellow to dark red-brown liquid, with a strong odor of thymol

density (at $20^{\circ} \mathrm{C}$ ): 0.915 to $0.935 \mathrm{~g} / \mathrm{cm}^{3}$

refractive index (at $20^{\circ} \mathrm{C}$ ): 1.490 to 1.505

optical rotation: $-7^{\circ}$ to $+3^{\circ}$

flash point: $58^{\circ} \mathrm{C}$

$\alpha$-thujen: $0.2-1.5 \%$

$\beta$-myrcene: $1.0-3.0 \%$

$\alpha$-terpinene: $0.9-2.6 \%$

$\rho$-cymene: $14.0-28.0 \%$

$\gamma$-terpinene: $4.0-12.0 \%$

linalool: $1.5-6.5 \%$

terpinen-4-ol: $0.1-2.5 \%$

methyl carvacrol ether: $0.05-1.5 \%$

thymol: $37.0-55.0 \%$

carvacrol: $0.5-5.5 \%$ 


\subsection{Microorganisms and Antibacterial Activity Assessment of Essential Oils}

Five bacterial strains were used as follows: Enterococcus faecalis (isolated from water and identified in the Institute of Fermentation Technology and Microbiology, Lodz University of Technology, Żeromskiego, Poland), Escherichia coli ATCC10536, Pseudomonas aeruginosa ATCC15442, Staphylococcus epidermidis ATCC12228, and Staphylococcus saprophyticus DSM4853. The strains designated ATCCs originated from American Type Culture Collection and a DSM strain was obtained from Leibniz Institute DSMZ-Deutsche Sammlung von Mikroorganismen und Zellkulturen, $\mathrm{GmbH}$. The microorganisms were activated through double passaging on TSA medium (trypticase soy agar) Oxoid, UK $\left(37^{\circ} \mathrm{C}, 48 \mathrm{~h}\right)$.

\section{Microatmosphere Method}

The essential oils' activity in the vapor phase was determined by the microatmosphere method. The suspensions of the tested bacteria were prepared in a physiological salt solution $(\mathrm{NaCl} 8.5 \mathrm{~g} / \mathrm{L})$, later standardized to the density of about $10^{8} \mathrm{CFU} / \mathrm{mL}$, and in the amount of $0.03 \mathrm{~mL}$ of a particular microorganism, these were transferred onto the TSA medium. Non-woven viscose discs of $55 \mathrm{~mm}$ in diameter were soaked with $0.5 \mathrm{~mL}$ of an appropriate essential oil in DMSO solution, which resulted in three different microatmospheres $\left(0.054 ; 0.106\right.$ and $\left.0.214 \mu \mathrm{L} / \mathrm{cm}^{3}\right)$. The discs were placed on the lid of the plate (inhibition in the gas phase) and cultured upside-down. During culturing, the discs were on the bottom lid. Subsequently, the plates were secured with Petri film. Petri dishes were kept at $4{ }^{\circ} \mathrm{C}$ for $2 \mathrm{~h}$, and then incubated at $37^{\circ} \mathrm{C}$ for $24 \mathrm{~h}$. After incubation, each agar medium with inoculated bacteria was transferred into $50 \mathrm{~mL}$ of sterile water to rinse the biomass off, and the optical density (OD) of the suspension was measured at the wavelength $560 \mathrm{~nm}$ with the use of TriStar2S LB942 spectrophotometer (Berthold Technologies, Bad Wildbad, Germany). The reference sample was the specific bacteria culture grown without the essential oil. Positive controls were the bacteria cultures with the non-woven viscose discs soaked with $0.5 \mathrm{~mL}$ of $96 \%$ ethanol solution. Antimicrobial activity of DMSO was also checked analogically and no adverse effect on the tested microorganisms was observed. The experiments were conducted in triplicate and results were presented as an average value with a standard deviation.

The essential oils vapor activity against bacteria was expressed as a percent of biomass loss according to Formula (1), as follows:

$$
I(\%)=\frac{A_{s}-A_{b}}{A_{s}} \cdot 100 \%
$$

where $I$-biomass loss (\%); $A_{s}$-an absorbance at $560 \mathrm{~nm}$ of the biomass suspension of the bacteria grown without the essential oil; $A_{b}$-an absorbance at $560 \mathrm{~nm}$ of the biomass suspension of the bacteria grown in the microatmosphere of the essential oil vapors.

\subsection{Statistical Analysis}

All of the results were expressed as the mean \pm SD of three independent experiments. One-way ANOVA was used in order to compare the statistical differences $(p<0.05)$.

\section{Conclusions}

The best inhibitory effect in vapor phase was noted for Matricaria chamomilla L. essential oil at the lowest concentration $\left(0.054 \mu \mathrm{L} / \mathrm{cm}^{3}\right)$. Both mixtures of chamomile (Matricaria chamomilla L.) essential oil with two species of sage (Salvia officinalis L. and Salvia lavandulaefolia Vahl.) acted antagonistically, lowering the antibacterial activity expressed by the individual oil applied solely. Juniper and Salvia officinalis essentials oils, at the concentrations tested, increased the growth of at least one of bacteria species. Salvia lavandulaefolia Vahl. essential oil inhibited all bacteria only at the highest concentration $0.214 \mu \mathrm{L} / \mathrm{cm}^{3}$. This essential oil is also socially accepted and, in low concentrations, is used to alleviate irritations to human skin. The thyme oil (Thymus vulgaris L.), at its lowest concentration 
$0.054 \mu \mathrm{L} / \mathrm{cm}^{3}$, reduced the growth of all bacterial species. However, both chamomile and thyme essential oils were chosen for further research in the biotextronics pantiliner system.

Author Contributions: Conceptualization, E.F., A.K.-S., K.S. and M.F.; formal analysis, E.F.; investigation, E.F. and A.K.-S.; methodology, E.F., A.K.-S. and K.Ś.; resources, A.K.-S. and K.Ś.; supervision, A.K.-S., K.Ś. and M.F.; visualization, E.F. and M.F.; writing—original draft preparation, E.F.; writingreview and editing, E.F., A.K.-S., K.Ś. and M.F. All authors have read and agreed to the published version of the manuscript.

Funding: This research was partially funded by the project "Biotextronics system for the prevention and support of the lower urinary tract inflammations" by Inkubator Innowacyjności +, Poland (eng. Incubator of Innovation +), which is designed for pre-implementation projects.

Institutional Review Board Statement: Not applicable.

Informed Consent Statement: Not applicable.

Conflicts of Interest: The authors declare no conflict of interest.

Sample Availability: Samples of the essential oils are available from the authors.

\section{References}

1. Kunttu, K. Urinary Tract Infections in Young Women; Ylioppilaiden Terveydenhoitosäätiö: Helsinki, Finland, 2010 ; pp. 1-12.

2. Sekulowa, J. Domowy Poradnik Medyczny (eng. Home Medical Guide); Kazimierz, J., Ed.; Państwowy Zakład Wydawnictw Lekarskich: Warsaw, Poland, 1991; pp. 335-338.

3. Urinary Tract Infection (UTI). A Guide for Women; International Urogynecological Association: Burnsville, MN, USA, 2012; pp. $1-2$.

4. Mashall, K. Interstitial Cystitis: Understanding the Syndrome. Altern. Med. Rev. 2003, 8, 1-12.

5. Kawecki, D. Infekcje w Układzie Moczowym (eng. Infections in Urinary Tract. In Uroginekologia Schorzenia dna Miednicy (eng. Uroginecology Diseases of Pelvic Floor); Ewa, B., Ed.; Via Medica: Gdańsk, Poland, 2017; pp. 399-406.

6. Adamkiewicz, K.; Borkowski, A.; Krzeski, T.; Leńko, J.; Marczyńska, A.; Mazurek, L.J.; Stolarczyk, J.; Zieliński, J. UROLOGIA Podręcznik dla Studentów Medycyny (eng. UROLOGY Manual for Medical Students); Leńko, J., Ed.; Państwowy Zakład Wydawnictw Lekarskich: Warsaw, Poland, 1987; pp. 130-133.

7. Holecki, M.; Duława, J.; Hryniewicz, W.; Imiela, J.; Klinger, M.; Pawlik, K.; Wanke-Rytt, M. Rekomendacje Diagnostyki, Terapii i Profilaktyki Zakażeń Układu Moczowego u Dorostych (eng. Recommendations for Diagnostics, Therapy and Prevention of Urinary Tract Infections in Adults); Hryniewicz, W., Holecki, M., Eds.; Narodowy Instytut Leków: Warsaw, Poland, 2015; pp. 7-46.

8. Welsh, P.C. Campbell's Urology, 8th ed.; The Curtis Center: Philadelphia, PA, USA, 2002; Volume 1, pp. 572-580.

9. Boone, T.B.; Coburn, M.; Fishman, I.J.; Gousse, A.E.; Greer, J.A.; Griffith, D.P.; Gurpinar, T.; Harding, J.R.; Hinson, J.L.; Lerner, S.P. Nawracajace Zakażenia Dróg Moczowych (eng. Recurrent urinary Tract Infections). In Podstawy Urologii (eng. Basics of Urology); Wydawnictwo Lekarskie PZWL: Warsaw, Poland, 1999; pp. 58-63.

10. Amalaradjou, M.A.R.; Venkitanarayanan, K. Natural Approaches for Controlling Urinary Tract Infections. Urin. Tract Infect. 2011, 13, 227-244. [CrossRef]

11. Van Vuuren, S.F.; Naidoo, D. An antimicrobial investigation of plants used traditionally in southern Africa to treat sexually transmitted infections. J. Ethnopharmacol. 2010, 130, 552-558. [CrossRef] [PubMed]

12. Schwiertz, A.; Duttke, C.; Hild, J.; Muller, H.J. In vitro activity of essential oils on microorganisms isolated from vaginal infections. Int. J. Aromather. 2006, 16, 169-174. [CrossRef]

13. Gniewosz, M.; Kraśniewska, K.; Weglarz, Z.; Przybył, J.L. Porównanie przeciwdrobnoustrojowej aktywności etanolowego i wodnego ekstraktu z szałwii lekarskiej (Salvia officinalis L.) (eng. Comparison of the antimicrobial activity of ethanolic and aqueous sage extracts from sage (Salvia officinalis L.)). Bromatologia i Chemia Toksykologiczna-XLV 2012, 3, 743-748.

14. Darwish, M.A.; Al-Ramamneh, E.A.; Abu-Dieyeh, I.S.Z.; Al-Nawaiseh, M.; Albdour, T. Determination of essential oil bioactive components and rosmarinic acid of Salvia officinalis cultivated under different intra-row spacing. Not. Sci. Biol. 2013, 5, 198-203. [CrossRef]

15. Russo, A.; Formisano, C.; Rigano, D.; Senatore, F.; Delfine, S.; Cardile, V.; Rosselli, S.; Bruno, M. Chemical composition and anticancer activity of essential oils of Mediterranean sage (Salvia officinalis L.) grown in different environmental conditions. Food Chem. Toxicol. 2013, 55, 42-47. [CrossRef]

16. Kałużna, O. Badanie Wpływu Rożnych Stężeń Olejku Eterycznego i Naparu z Szałwii Lekarskiej Salvia officinalis L. na Tempo Wzrostu Hodowli Płynnej Bakterii Escherichia coli Szczepów MC4100 i MC4100 $C$ ClpB (eng. Study of the Effect of Various Concentrations of Essential Oil and Infusion of Salvia officinalis L. on the Growth Rate of the Liquid Culture of Escherichia coli Strains MC4100 and MC4100 $\Delta$ ClpB). Available online: https: / / docplayer.pl/26459575-Badanie-wplywu-roznych-stezen-olejkueterycznego-i-naparu-z-szalwii-lekarskiej-salvia-officinalis.html (accessed on 10 September 2021). 
17. Kędzia, A.; Dera-Tomaszewska, B.; Ziółkowska-Klinkosz, M.; Wojtaszek-Słomińska, A.; Czernecka, B. Działanie olejku szałwiowego (Oleum Salviae lavandulaefoliae) na bakterie tlenowe izolowane z jamy ustnej, dróg oddechowych i przewodu pokarmowego (eng. Activity of Oleum salviae (Spanish sage essential oil) against aerobic bacteria isolated from oral cavity, respiratory and gasrtointestinal tract). Postępy Fitoterapii 2011, 4, 238-242.

18. Porres-Martínez, M.; Carretero Accame, E.; Gómez-Serranillos, P. Pharmacological activity of Salvia lavandulifolia and chemical components of its essential oil. A review. Lazaroa 2013, 34, 237-254. [CrossRef]

19. Kazemi, M. Chemical composition and antimicrobial activity of essential oil of Matricaria chamomilla. Bulletin of Environment. Pharmacol. Life Sci. 2014, 3, 148-153.

20. The Longwood Herbal Task Force. Gardiner P. Chamomile (Matricaria recutita, Anthemis nobilis). 1999, pp. 1-21. Available online: https: / / tratamientocelular.com/papers/cmran.pdf (accessed on 15 September 2021).

21. Hosseinpour, M.; Mobini-Dehkordi, M.; Saffar, B.; Teimori, H. Antiproliferative effects of Matricaria chamomilla on Saccharomyces cerevisiae. J. HerbMed Pharmacol. 2013, 2, 49-51.

22. Kędzia, A.; Dera-Tomaszewska, B.; Ziółkowska-Klinkosz, M.; Kędzia, A.W.; Kochańska, B.; Gębska, A. Aktywność olejku tymiankowego (Oleum Thymi) wobec bakterii tlenowych (eng. Activity of thyme essentials oil (Oleum Thymi) against aerobic bacteria). Postepy Fitoterapii 2012, 2, 67-71.

23. Sienkiewicz, M.; Wasiela, M. Aktywność olejków tymiankowego i lawendowego wobec opornych na antybiotyki szczepów klinicznych Pseudomonas aeruginosa (eng. Activity of thyme and lavender essential oils against antibiotic resistant clinical strains of Pseudomonas aeruginosa). Postępy Fitoterapii 2012, 3, 139-145.

24. Shabnum, S.; Muzafar, G.W. Essential oil composition of Thymus Vulgaris L. and their uses. J. Res. Dev. 2011, 11, 83-94.

25. Moghtader, M. Antifungal effects of the essential oil from Thymus vulgaris L. and comparison with synthetic thymol on Aspergillus niger. J. Yeast Fungal Res. 2012, 3, 83-88.

26. Filipowicz, N.H.; Kamiński, M.M.; Kurlenda, J.; Asztemborska, J. Antibacterial and antifungal activity of juniper berry oil and its selected components. Phytoth. Res. 2003, 17, 227-231. [CrossRef]

27. Pepeljnjak, S.; Kosalec, I.; Kalodera, Z.; Blazevic, N. Antimicrobial activity of juniper berry essential oil (Juniperus communis L., Cupressaceae). Acta Pharm. 2005, 55, 417-422. [PubMed]

28. Das, S.; Horvath, B.; Safranko, S.; Jokić, S.; Szechenyi, A.; Koszegi, T. Antimicrobial activity of chamomile essential oil: Effect of different formulations. Molecules 2019, 24, 4321. [CrossRef]

29. Wińska, K.; Mączka, W.; Łyczko, J.; Grabarczyk, M.; Czubaszek, A.; Szumny, A. Essential oils as antimicrobial agents—myth or real alternative? Molecules 2019, 24, 2130. [CrossRef]

30. Reyes-Jurado, F.; Navarro-Cruz, A.R.; Ochoa-Velasco, C.E.; Lopez-Malo, A.; Avila-Sosa, R. Essential oils in vapor phase as alternative antimicrobials: A review. Crit. Rev. Food Sci. 2020, 60, 1641-1650. [CrossRef]

31. Pierozan, M.K.; Pauletti, G.F.; Rota, L.; Santos, A.C.A.; Lerin, L.A.; Di Luccio, M.; Mossi, A.J.; Atti-Serafini, L.; Cansian, R.L.; de Oliveira, V.J. Chemical characterization and antimicrobial activity of essential oils of salvia L. species. Ciência e Tecnologia de Alimentos 2009, 29, 764-770. [CrossRef]

32. Martin, E.; Lingbeck, J.; Adams, J.; O’Bryan, C.; Crandall, P. Sweetgum: An ancient source of beneficial compounds with modern benefits. Pharm. Rev. 2015, 9, 1-11.

33. Longaray Delamare, A.P.; Moschen-Pistorello, I.T.; Artico, L.; Atti-Serafini, L.; Echeverrigaray, S. Antibacterial activity of the essential oils of Salvia officinalis L. and Salvia triloba L. cultivated in South Brazil. Food Chem. 2007, 100, 603-608. [CrossRef]

34. Cutillas, A.-B.; Carrasco, A.; Martinez-Gutierrez, R.; Tomas, V.; Tudela, J. Salvia officinalis L. essential oil from Spain: Determination of composition, antioxidant capacity, antienzymatic and antimicrobial bioactivitie. Int. J. Lab. Hematol. 2016, 38, 42-49.

35. Ghorbani, A.; Esmaeilizadeh, M. Pharmacological properties of Salvia officinalis and its components. J. Tradit. Complement. Med. 2017, 7, 433-440. [CrossRef]

36. Salehi, B.; Abu-Darwish, M.S.; Tarawneh, A.H.; Cabral, C.; Gadetskaya, A.V.; Salgueiro, L.; Hosseinabadii, T.; Rajabi, S.; Chandak, W.; Sharifi-Rad, M.; et al. Thymus spp. plants -food applications and phytopharmacy properties. Trends Food Sci. Technol. 2019, 85, 286-306. [CrossRef]

37. Rajkowska, K.; Nowak, A.; Kunicka-Styczyńska, A.; Siadura, A. Biological effects of various chemically characterized essential oils: Investigation of the mode of action against Candida albicans and HeLa cells. RSC Adv. 2016, 6, 97199-97207. [CrossRef]

38. Herman, A.; Herman, A.P. Essential oils and their constituents as skin penetration enhancer for transdermal drug delivery: A review. J. Pharm. Pharmacol. 2014, 67, 473-485. [CrossRef]

39. Jäger, W.; Buchbauer, G.; Jirovetz, L.; Fritzer, M. Percutaneous absorption of lavender oil from a massage oil. J. Soc. Cosmet. Chem. 1992, 43, 49-54.

40. Diliberto, J.J.; Usha, G.; Birnbaum, L.S. Disposition of citral in male Fischer rats. Drug Metab. Dispos. 1988, 16, 721-727.

41. Srivastava, J.K.; Gupta, S. Antiproliferative and apoptotic effects of chamomile extract in various human cancer cells. J. Agric. Food Chem. 2007, 55, 9470-9478. [CrossRef] [PubMed]

42. Mahdavia, B.; Ghorat, F.; Nasrollahzadeh, M.S.; Hosseyni-Tabara, M.; Rezaei-Seresht, H. Chemical composition, antioxidant, antibacterial, cytotoxicity, and hemolyses activity of essential oils from flower of Matricaria chamomilla var. chamomilla. Anti-Infect. Agents 2020, 18, 224-232. [CrossRef] 
43. Russo, R.; Corasaniti, M.T.; Bagetta, G.; Morrone, L.A. Exploitation of cytotoxicity of some essential oils for translation in cancer therapy. Evid.-Based Compl. Alt. Med. 2015, 397821,1-9. [CrossRef] [PubMed]

44. Kowalczyk, A.; Przychodna, M.; Sopata, S.; Bodalska, A.; Fecka, I. Thymol and thyme essential oil-new insights into selected therapeutic applications. Molecules 2020, 25, 4125. [CrossRef] [PubMed] 